Tropical Journal of Pharmaceutical Research April 2019; 18 (4): 791-797

ISSN: $1596-5996$ (print); 1596-9827 (electronic)

(C) Pharmacotherapy Group, Faculty of Pharmacy, University of Benin, Benin City, 300001 Nigeria.

\title{
Alpha-glucosidase inhibitory and antioxidant activities of various extracts of aerial parts of Fagonia indica Burm. F.
}

\author{
Atiq-ur-Rehman ${ }^{1,2 \star}$, Abida Latif ${ }^{1 \star}$, Nasir Abbas ${ }^{1}$, Imran Waheed ${ }^{3}$, Atta-ur- \\ Rehman $^{4}$, Muhammad Naeem Qaisar ${ }^{5}$ \\ ${ }^{1}$ University College of Pharmacy, University of the Punjab, Lahore, Pakistan, ${ }^{2}$ Faculty of Pharmacy, The University of Lahore, \\ ${ }^{3}$ Akhtar Saeed College of Pharmaceutical Sciences, Bahria Town, ${ }^{4}$ Department of Pharmacy, Forman Christian College, \\ Lahore, 5College of Pharmacy, University of Sargodha, Sargodha, Pakistan
}

*For correspondence: Email: atiqurrehman10@gmail.com, abidalatif43@yahoo.com; Tel: 03037848119,03018486803

\begin{abstract}
Purpose: To investigate in vitro antioxidant and anti-diabetic potentials of Fagonia indica Burm.f. Var. indica in order to provide scientific evidence for its traditional use.

Methods: Cold maceration method was employed for the preparation of extracts of aerial parts of the plant using chloroform, n-hexane, methanol and water as solvents. Total flavonoid and polyphenolic content of various extracts were determined by standard methods. The antioxidant and anti-diabetic activities of the extracts were determined using 1, 1-diphenyl-2-picrylhydrazyl (DPPH) and in vitro $\alpha$ glucosidase (maltase) inhibitory assays, respectively.

Results: Preliminary results indicated the presence of various phytochemicals in the extracts. The chloroform extract exhibited the highest contents of total flavonoids $(65.98 \pm 1.63 \mathrm{mg} \mathrm{QE} / \mathrm{g})$ and polyphenols $(26.75 \pm 1.09 \mathrm{mg} \mathrm{GAE} / \mathrm{g})$. This extract also showed the highest free radical scavenging $(64.74 \pm 1.43 \%)$ with $I C_{50}$ value of $34.18 \pm 5.57 \mu \mathrm{g} / \mathrm{mL}$ while the methanol extract exerted the highest $\alpha$ glucosidase (maltase) inhibitory activity (45.22 $\pm 0.46 \%$ ) with half-maximal concentration $\left(I_{50}\right)$ of 220.4 $\pm 0.41 \mu \mathrm{g} / \mathrm{mL}$.

Conclusion: The extracts of the aerial parts of Fagonia indica possess significant anti-diabetic and antioxidant effect, thus justifying the traditional use of the plant for treatment of diabetes.
\end{abstract}

Keywords: $\alpha$-Glucosidase, Antioxidant, Fagonia indica, Flavonoids, Polyphenols

\begin{abstract}
This is an Open Access article that uses a fund-ing model which does not charge readers or their institutions for access and distributed under the terms of the Creative Commons Attribution License (http://creativecommons.org/licenses/by/4.0) and the Budapest Open Access Initiative (http://www.budapestopenaccessinitiative.org/read), which permit unrestricted use, distribution, and reproduction in any medium, provided the original work is properly credited.

Tropical Journal of Pharmaceutical Research is indexed by Science Citation Index (SciSearch), Scopus, International Pharmaceutical Abstract, Chemical Abstracts, Embase, Index Copernicus, EBSCO, African Index Medicus, JournalSeek, Journal Citation Reports/Science Edition, Directory of Open Access Journals (DOAJ), African Journal Online, Bioline International, Open-J-Gate and Pharmacy Abstracts
\end{abstract}

\section{INTRODUCTION}

Diabetes mellitus (DM) is a chronic metabolic disorder which is characterized by an increase in blood glucose level (hyperglycemia) and causes disturbances in fat, protein and carbohydrate metabolism. It causes decline in insulin secretion or its action or both [1]. For the past few years the increase in the occurrence of diabetes has been observed [2]. The prevalence of diabetic patients has increased from 171 million to 366 million since 2000 and it is expected to rise even more by 2030 [3]. In type $2 \mathrm{DM}$, starch hydrolysis by the pancreatic alpha-amylase and the absorption of glucose by the intestinal alpha-glucosidases 
like maltase and sucrase results in postprandial hyperglycemia (PPHG) [4].

Alpha-glucosidase inhibitors suppress the PPHG effect by suppressing the hydrolysis of disaccharides into glucose monomers leading to decreased glucose absorption [5]. However, synthetic a-glucosidase inhibitors like acarbose are often reported with gastrointestinal side effects which include flatulence, abdominal pain and diarrhea [6]. Therefore, it is the need of hour to search for effective and safe alternative $\alpha$ glucosidase inhibitors showing no side effects. One of the potential approaches to find out a new agent of drug for treating diabetes, especially type $2 \mathrm{DM}$ is the mechanism of a-glucosidase inhibition [7]. Diabetes contributes in causing complications due to free radical reactions [8]. The use of antioxidants in diabetes therapy may prevent diabetic complications [9]. Natural inhibitors of $\alpha$-glucosidase and $\alpha$-amylase obtained from the plants can be used effectively in the management of postprandial hyperglycemia having minimum side effects [10]. $F$. indica Burm.f. Var. indica (family: Zygophyllaceae) is pruinose glandular or glabrous pale green shrublet having $55 \mathrm{~cm}$ height. It is distributed in Pakistan and westwards to North and East tropical Africa $[11,12]$. It is used as a hypoglycemic agent in a folklore system [13]. Anti-diabetic activity of this plant with a well-defined mechanism has not been evaluated and studied so far. Moreover, no report has shown the antioxidant properties of the plant extracts. This study tends to investigate phytochemicals, the total content of flavonoids, polyphenols, in vitro antioxidant and antidiabetic potential of $F$. indica Var. indica to provide the scientific evidence for the folkloric/traditional use of this plant in managing diabetes.

\section{EXPERIMENTAL}

\section{Chemicals and reagents}

Solvents and reagents of analytical grade were used during the study. 1, 1-diphenyl-2picrylhydrazyl (DPPH), rat intestinal acetone powder for maltase, Butylated hydroxytoluene (BHT) and FC (Folin-Ciocalteu) reagent were purchased from Sigma-Chemical Co. (USA). Gallic acid and quercetin were purchased from Sigma Life Science (Germany). Methanol, chloroform, n-hexane, hydrochloric acid, copper sulphate, ferric chloride, aluminium nitrate, potassium acetate, sodium hydroxide, acetic acid, sodium phosphate, lead acetate, potassium sodium tartrate and lead acetate were obtained from E. Merck (Germany).

\section{Plant collection and authentication}

The aerial parts of the plant were collected from Cholistan desert; Bahawalpur, Pakistan and the plant were authenticated by a plant taxonomist (Prof Dr Zaheer-ud-din Khan, Botany Department, Government College University, Lahore, Pakistan). A voucher specimen (GCHerb-Bot. 2967) was deposited in Dr Sultan Ahmad Herbarium of the same university.

\section{Sample preparation and extraction}

The aerial parts of the plant were air dried and crushed into coarse powder. After drying the powder was extracted sequentially with solvents n-hexane, chloroform, methanol and water of increasing polarity by a cold maceration method with frequent stirring. The filtrates of various extracts were concentrated using a rotary vacuum evaporator (Heidolph, Laborata 4002, Germany) under reduced pressure at $40{ }^{\circ} \mathrm{C}$ and were stored at $0-4{ }^{\circ} \mathrm{C}$ for further use.

\section{Phytochemical evaluation (qualitative chemical examination)}

Various extracts of the plant were subjected to a qualitative phytochemical screening to identify phytoconstituents (flavonoids, saponins, terpenoids, phenols, glycosides and alkaloids) responsible for antioxidant and anti-diabetic activities using the standard procedures as described by Trease and Evan, and Sofowara $[14,15]$.

\section{Total flavonoid content (TFC)}

TFCs in various extracts were determined following the method of Chang et al [16] with minor modification. Stock solutions of quercetin (1 $\mathrm{mg} / \mathrm{mL}$ ) and the extracts $(1 \mathrm{mg} / \mathrm{mL}$ ) were prepared in methanol. Different concentrations $(10-120 \mu \mathrm{g} / \mathrm{mL})$ of the standard quercetin were prepared in methanol. In order to prepare the working solution, $200 \mu \mathrm{L}$ was taken in the test tubes for each of the standard and sample, and finally the volume was made up to $1 \mathrm{~mL}$ by the addition of methanol. After, $1 \mathrm{M}$ potassium acetate $(100 \mu \mathrm{L}), 10 \% \mathrm{w} / \mathrm{v}$ of aluminium nitrate solution $(100 \mu \mathrm{L})$ and $4.6 \mathrm{~mL}$ of distilled water were added to these test tubes. The contents were mixed thoroughly and incubated at room temperature for 45 minutes. The absorbance was measured at $\lambda_{\max }$ of $415 \mathrm{~nm}$ using a UV spectrophotometer (UV-1800, Shimadzu, Japan). Blank was prepared similarly as the sample but no sample/standard was added to it. TFC was determined from the standard calibration curve of 
quercetin (milligrams of quercetin equivalent $/ \mathrm{g}$ of plant extract) using linear regression equation.

\section{Total polyphenolic content (TPC)}

TPCs of the extracts were investigated following the method described by Slinkard and Singleton [17] with minor modification. Stock solutions of gallic acid $(1 \mathrm{mg} / \mathrm{mL})$ and the extracts $(1 \mathrm{mg} / \mathrm{mL})$ were prepared using methanol as solvent. Concentrations in the range of $10-120 \mu \mathrm{g} / \mathrm{mL}$ of the standard gallic acid were prepared to draw the standard calibration curve. $200 \mu \mathrm{L}$ was taken separately in the test tubes for standard, sample and the volume was made up to $1 \mathrm{~mL}$ with methanol. After, $200 \mu \mathrm{L}$ of $\mathrm{FC}$ reagent was added to and the contents, after mixing thoroughly were kept for 4 minutes. Later, the solution of sodium carbonate $(15 \% \mathrm{w} / \mathrm{v}, 1 \mathrm{~mL})$ was added and stored at $25^{\circ} \mathrm{C}$ for $2 \mathrm{~h}$. The absorbance was measured at $\lambda_{\max }$ of $760 \mathrm{~nm}$ wavelength using a spectrophotometer. Blank was prepared similarly, but no standard/sample was added to it. TPC was determined by using calibration curve of standard (milligrams of gallic acid equivalent/g of plant extract) using linear regression equation.

\section{Evaluation of DPPH free radical scavenging activity}

The DPPH free radical scavenging activity of the extracts was investigated using DPPH (1, 1diphenyl-2-picrylhydrazyl) assay as described by Lee and Shibamoto [18] and compared with a standard antioxidant BHT. Samples at concentrations (15 - $75 \mu \mathrm{g} / \mathrm{mL}$ ) were dissolved in a methanolic solution of DPPH ( $3 \mathrm{~mL}, 0.1 \mathrm{mM})$. The solutions after shaking vigorously were kept at room temperature for $1 \mathrm{~h}$. Control contained 3 $\mathrm{mL}$ of the DPPH solution and was treated like the standard/sample. The absorbance of all extracts, standard and control was measured at $\lambda_{\max }$ of $517 \mathrm{~nm}$. Methanol was used as blank. Regression equation was applied to calculate IC50 values. Percent free radical scavenging activity (\% FRSA) was calculated as in Eq 1 [19].

$\% \mathrm{FRSA}=\{(\mathrm{Ac}-\mathrm{Ae}) / \mathrm{Ac})\} 100$.

where $A c=$ the absorbance of control and $A e=$ the absorbance of extract.

For each extract the assay was repeated thrice and the mean of three values was taken.

\section{Alpha-glucosidase inhibitory assay}

The anti-diabetic activity of various extracts was determined by alpha-glucosidase (maltase) inhibitory assay following the standard method of
Dahlqvist [20] with minor modification. Briefly, rat intestinal acetone powder $(1 \mathrm{~g})$ was mixed with $10 \mathrm{~mL}$ sodium phosphate buffer $(\mathrm{pH} 7,0.1 \mathrm{M})$ and was sonicated for 30 seconds (12 times) with a break of 15 second to prevent heat buildup. Later, centrifugation at $10,000 \mathrm{~g}$ at $4{ }^{\circ} \mathrm{C}$ for 10 minutes, the resultant supernatant collected was labeled as rat intestinal $\alpha-$ glucosidase (Maltase enzyme). Enzyme inhibition was determined by incubating the solution of an enzyme $(20 \mu \mathrm{L})$, phosphate buffer $(100 \mu \mathrm{L}, 0.1 \mathrm{M})$ at $\mathrm{pH} 7.0$, maltose solution (37 $\mathrm{mM}$ ) and the solutions of various extracts of the plant with varying concentrations of $20-100$ $\mu \mathrm{g} / \mathrm{mL}$ at $37{ }^{\circ} \mathrm{C}$ for $30 \mathrm{~min}$. Acarbose (a reference standard) at various concentrations (20 - $100 \mu \mathrm{g} / \mathrm{mL}$ ) was used as $\alpha$-glucosidase inhibitor. The mixtures were placed in boiling water for 5 minutes to terminate the reaction. Using the glucose oxidase method of Bergmeyer and Bernt [21], the amount of glucose released was determined. Alpha-glucosidase (maltase) inhibition $(\mathrm{H})$ was calculated using Eq 2 [22].

$H(\%)=\{(\mathrm{Ac}-\mathrm{Ae}) / \mathrm{Ac})\} 100$

where $A c=$ the absorbance of control and $A e=$ the absorbance of extract.

\section{Statistical analysis}

Assays were conducted thrice and the results are presented as mean \pm SD. Statistical analysis was performed using one-way analysis of variance (ANOVA) followed by Tukey multiple comparison test (Graph Pad Prism 5.0). Differences were considered to be statistically significant at $p<$ 0.05 .

\section{RESULTS}

\section{Phytochemical profile}

Screening of phytochemical constituents of various extracts showed the presence of phytochemicals as shown in Table 1.

\section{Total flavonoid content (TFC)}

TFCs of the extracts were determined from the standard quercetin calibration curve using linear regression equation $(Y=0.001 x+0.0071)$ with a correlation coefficient $(R)=0.998574$. The results of TFCs of the extracts are presented in Table 2. It was between $18.891 \pm 0.54 \mathrm{mg} \mathrm{QE} / \mathrm{g}$ to $65.98 \pm 1.63 \mathrm{mg} \mathrm{QE} / \mathrm{g}$ of dried extract. According to Table 2, the chloroform extract showed the highest TFC of $65.98 \pm 1.63 \mathrm{mg}$ of QE $/ \mathrm{g}$ of dried extract. It was followed by $n$-hexane, methanol and water extracts. 
Table 1: Phytochemical screening profile of $F$. indica

\begin{tabular}{lcccc}
\hline Phytoconstituent & HE & CE & ME & AE \\
\hline Saponins & + & + & + & + \\
Terpenoids & + & + & + & + \\
Glycosides & + & + & + & + \\
Flavonoids & + & + & + & + \\
Tannins & + & + & + & + \\
Phenols & + & + & + & + \\
Proteins & - & + & + & + \\
Alkaloids & - & - & + & + \\
Anthraquinones & - & - & - & - \\
Carbohydrates & - & + & + & - \\
Coumarins & + & + & + & + \\
Fats and oils & + & + & - & -
\end{tabular}

HE: n-hexane extract; CE: Chloroform extract; ME: Methanol extract; AE: aqueous extract; (-): the absence and $(+)$ : the presence of phytoconstituents

\section{Total polyphenol content (TPC)}

TPCs of the extracts were determined from the standard calibration curve using linear regression equation $(Y=0.0037 x+0.0403)$ with $a$ correlation coefficient $(R)=0.99736$. The results of TPCs of the extracts are presented in Table 2 and were ranged from $4.96 \pm 1.20$ to $26.75 \pm 1.09$ $\mathrm{mg}$ of $\mathrm{GAE} / \mathrm{g}$ of the extract. The chloroform extract showed the highest TPC of $26.75 \pm 1.09$ $\mathrm{mg}$ of $\mathrm{GAE} / \mathrm{g}$ of the extract which was followed by methanol, n-hexane and water extracts.

Table 2: Total flavonoid and polyphenol contents of plant extracts

\begin{tabular}{lcc}
\hline Extract & $\begin{array}{c}\text { Total flavonoid } \\
\text { content } \\
\text { (mg of } \mathbf{Q E} / \mathbf{g} \text { of } \\
\text { dried extract) }\end{array}$ & $\begin{array}{c}\text { Total polyphenol } \\
\text { contents } \\
\text { (mg of GAE/g of } \\
\text { dried extract) }\end{array}$ \\
\hline $\mathrm{n}$-Hexane & $57.44 \pm 1.81$ & $11.67 \pm 0.43$ \\
Chloroform & $65.98 \pm 1.63$ & $26.75 \pm 1.09$ \\
Methanol & $24.16 \pm 1.27$ & $19.45 \pm 0.95$ \\
Water & $18.89 \pm 0.54$ & $4.96 \pm 1.20$ \\
\hline Values are mean $\pm \mathrm{SD}(\mathrm{n}=3)$ &
\end{tabular}

\section{Antioxidant activity}

Various extracts of the plant show \% DPPH free radical scavenging (Table 3 ). The results showed that the antioxidant activity increases with increase in concentration of the extract/ sample. Chloroform extract exhibited the highest percentage of scavenging DPPH free radical as compared to other extracts (64.74 $\pm 1.43 \%$ inhibition at the concentration of $75 \mu \mathrm{g} / \mathrm{mL}$ ).

The $\mathrm{IC}_{50}$ (concentration of a plant extract that is required to scavenge $50 \%$ of DPPH free radical) of the extracts are presented in Table 4. Lower the value of $I_{50}$, greater will be free radical scavenging activity. The chloroform extract exhibited the lowest value of $\mathrm{IC}_{50}$, i.e., $34.185 \pm$ $5.57 \mu \mathrm{g} / \mathrm{mL}$ compared to the other extracts. The aqueous extract showed low antioxidant activity, compared to standard (BHT).

Table 3: Percent scavenging of DPPH free radical by various extracts/samples of the plant

\begin{tabular}{|c|c|c|}
\hline Extract & $\begin{array}{c}\text { Concentration } \\
\text { of extracts } \\
(\mu \mathrm{g} / \mathrm{mL})\end{array}$ & $\begin{array}{c}\text { Radical } \\
\text { scavenging of } \\
\text { DPPH (mean } \pm \\
\text { SD } \\
\end{array}$ \\
\hline n-Hexane & 15 & $36.21 \pm 0.47$ \\
\hline \multirow[t]{4}{*}{ extract } & 30 & $42.20 \pm 2.87$ \\
\hline & 45 & $48.68 \pm 2.87$ \\
\hline & 60 & $51.79 \pm 0.47$ \\
\hline & 75 & $57.55 \pm 0.43$ \\
\hline Chloroform & 15 & $42.20 \pm 2.87$ \\
\hline \multirow[t]{4}{*}{ extract } & 30 & $49.88 \pm 1.19$ \\
\hline & 45 & $55.63 \pm 0.48$ \\
\hline & 60 & $61.63 \pm 0.71$ \\
\hline & 75 & $64.74 \pm 1.43$ \\
\hline Methanol & 15 & $40.28 \pm 0.47$ \\
\hline \multirow[t]{4}{*}{ Extract } & 30 & $44.60 \pm 2.63$ \\
\hline & 45 & $51.79 \pm 0.47$ \\
\hline & 60 & $55.15 \pm 2.15$ \\
\hline & 75 & $60.91 \pm 2.56$ \\
\hline Water & 15 & $30.21 \pm 0.47$ \\
\hline \multirow[t]{4}{*}{ Extract } & 30 & $38.36 \pm 0.71$ \\
\hline & 45 & $44.60 \pm 2.63$ \\
\hline & 60 & $48.28 \pm 2.87$ \\
\hline & 75 & $53.23 \pm 0.47$ \\
\hline \multirow[t]{5}{*}{ Standard BHT } & 15 & $48.68 \pm 2.87$ \\
\hline & 30 & $56.59 \pm 0.95$ \\
\hline & 45 & $64.74 \pm 1.43$ \\
\hline & 60 & $78.17 \pm 0.71$ \\
\hline & 75 & $82.73 \pm 0.95$ \\
\hline
\end{tabular}

Data are showed as mean \pm SD $(\mathrm{n}=3) ; \quad p<0.001$ when compared to control and the standard, acarbose (comparison test)

Table 4: $\mathrm{IC}_{50}$ of various extracts of the plant

\begin{tabular}{lc}
\hline Standard/extract & $\begin{array}{c}\mathbf{I C}_{50} \text { of DPPH-radical } \\
\text { scavenging }(\boldsymbol{\mu g} / \mathbf{m L})\end{array}$ \\
\hline Standard $(\mathrm{BHT})$ & $17.82 \pm 3.56$ \\
n-Hexane extract & $43.63 \pm 4.73^{\mathrm{C}}$ \\
Chloroform extract & $34.18 \pm 5.57^{\mathrm{a}}$ \\
Methanol extract & $52.75 \pm 4.60^{\mathrm{C}}$ \\
Water extract & $63.69 \pm 4.54^{\mathrm{C}}$ \\
\hline
\end{tabular}

Values are expressed as mean \pm SD $(n=3)$. Values are relative to the standard $(\mathrm{BHT}) ; .^{\mathrm{a}^{*}} p<0.05$ and ${ }^{\mathrm{C}^{\star \star \star}} p$ $<0.001$ in comparison with reference standard $(\mathrm{BHT})$

\section{Maltase inhibition}

The assay showed that various extracts of the plant have a-glucosidase (maltase) inhibition. The methanol extract exhibited the highest maltase inhibition followed by aqueous extract at the concentrations of $20-100 \mu \mathrm{g} / \mathrm{mL}$ in a concentration-dependent manner. n-Hexane and chloroform extracts showed minimum maltase inhibitory activity and percentage inhibition increased at a lower level even by increasing the concentration of extracts used. 
The maximum concentration of the methanol extract $(100 \mu \mathrm{g} / \mathrm{mL})$ showed the highest maltase inhibition of $45.22 \pm 0.46 \%$ and the standard reference (acarbose) exhibited $67.41 \pm 0.92 \%$ inhibition at the same concentration (Table 5). It has been suggested that methanol extract is rich in phytoconstituents that have the potential in managing diabetes. The results were evaluated by comparing with the standard (acarbose) as presented in Table 5. A significant decrease in ( $p$ $<0.001)$ in the levels of glucose in blood was found among various extracts and standard drug in comparison to diabetic control.

Table 6: $\mathrm{IC}_{50}$ of various extracts

\begin{tabular}{lc}
\hline Standard/extract & $\begin{array}{c}\mathbf{I C}_{50} \text { values of maltase } \\
\text { inhibition }(\boldsymbol{\mu g} / \mathbf{m L})\end{array}$ \\
\hline Acarbose (standard) & $32.51 \pm 0.85$ \\
n-Hexane & $710.69 \pm 42.26$ \\
Chloroform & $579.31 \pm 24.48$ \\
Methanol & $220.40 \pm 0.41$ \\
Water & $236.18 \pm 0.85$ \\
\hline
\end{tabular}

Results are mean \pm standard deviation $(n=3)$. Maximum concentration taken was $100 \mu \mathrm{g} / \mathrm{mL} ;{ }^{* * *} p<$ 0.001 compared with standard (acarbose)

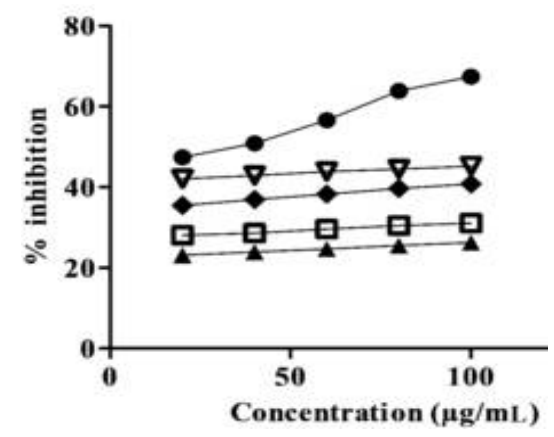

Figure 1: $\alpha$-Glucosidase (maltase) inhibition by $F$. indica extracts. Key: - acarbose, $\quad \nabla$ methanol extract, $\boldsymbol{\nabla}$ water extract, $\square$ chloroform extract, $\boldsymbol{\Delta} \mathrm{n}$ hexane extract

The $I_{50}$ of various extracts and standard (acarbose) are shown in Table 6. The results show that the smaller the $\mathrm{IC}_{50}$ value, the higher the anti-diabetic activity. Methanol extract was found to have smaller $\mathrm{IC}_{50}$ value in comparison to other extracts. $\mathrm{IC}_{50}$ values of all the extracts showed significant results $(p<0.001)$. The maltase inhibitory activity of various extracts and standard (acarbose) is shown in Figure 1. Inhibition of maltase was observed to be increased with increase in the concentration of the extracts.

\section{DISCUSSION}

Keeping the blood glucose level at normal values is a crucial strategy in controlling diabetes with its complications [4]. Therapeutic strategy for the management of diabetes is to decrease PPHG. It is done by the hindrance in glucose absorption by inhibiting carbohydrate metabolizing enzymes (alpha-amylase and alpha-glucosidase) in the gastrointestinal tract. Alpha-glucosidase inhibitors block the action of a-glucosidase enzymes in the small intestine, which limit the conversion of oligo and disaccharides into monosaccharides [23].

The plant under study exhibited a-glucosidase (maltase) inhibition. Methanol extract was found to show the most effective anti-diabetic activity among all the extracts analyzed. Although the extracts (chloroform and n-hexane) have DPPH inhibition (antioxidant activity) at a remarkable level but have less hypoglycemic activity. The study suggests that methanol solvent is efficient to extract hypoglycemic constituents from this plant and this extract exhibiting the maximum activity makes it a target for the isolation and characterization of responsible constituents. $\mathrm{DPPH}$, a free radical has a deep violet colour. It accepts a hydrogen $(\mathrm{H})$ atom or an electron and converts into a stable diamagnetic molecule [24]. The value of absorbance decreases due to the presence of phenolic molecule and the reaction of free radical with antioxidant compound.

Table 5: $\alpha$-Glucosidase (maltase) inhibitory activity of $F$. indica extracts

\begin{tabular}{lccccc}
\hline $\begin{array}{l}\text { Extract conc. } \\
(\mu \mathrm{g} / \mathrm{mL})\end{array}$ & $\begin{array}{c}\text { Inhibitory } \\
\text { activity (\%) } \\
\text { exhibited by } \\
\text { Standard } \\
\text { (acarbose) }\end{array}$ & $\begin{array}{c}\text { Inhibitory } \\
\text { activity (\%) } \\
\text { exhibited by n- } \\
\text { hexane extract }\end{array}$ & $\begin{array}{c}\text { Inhibitory } \\
\text { activity (\%) } \\
\text { exhibited by } \\
\text { chloroform } \\
\text { extract }\end{array}$ & $\begin{array}{c}\text { Inhibitory } \\
\text { activity (\%) } \\
\text { exhibited by } \\
\text { methanol } \\
\text { extract }\end{array}$ & $\begin{array}{c}\text { Inhibitory } \\
\text { activity }(\%) \\
\text { exhibited by } \\
\text { aqueous } \\
\text { extract }\end{array}$ \\
\hline 20 & $47.45 \pm 0.77$ & $23.18 \pm 0.30$ & $28.12 \pm 0.07$ & $42.12 \pm 0.23$ & $35.51 \pm 0.87$ \\
40 & $50.92 \pm 0.46$ & $23.95 \pm 0.23$ & $28.65 \pm 0.15$ & $42.91 \pm 0.23$ & $36.97 \pm 0.69$ \\
60 & $56.62 \pm 0.92$ & $24.73 \pm 1.00$ & $29.66 \pm 0.23$ & $43.91 \pm 0.30$ & $38.28 \pm 0.46$ \\
80 & $63.86 \pm 0.84$ & $25.57 \pm 0.92$ & $30.50 \pm 0.30$ & $44.53 \pm 0.61$ & $39.67 \pm 0.92$ \\
100 & $67.41 \pm 0.92$ & $26.27 \pm 0.15$ & $31.12 \pm 0.15$ & $45.22 \pm 0.46$ & $40.83 \pm 0.38$ \\
\hline
\end{tabular}

Data are mean \pm SD $(n=3) ; \quad p<0.001$, compared to diabetic control and positive control (acarbose) 
This study showed that the chloroform extract, which contains the highest content of flavonoids and polyphenols, exhibited the highest antioxidant activity.

The phytochemical investigation of this plant exhibited positive results for triterpenoids, saponins, flavonoids, phenolics, alkaloids, steroids and tannins. The bioactive compounds obtained from various plants have been reported to have anti-diabetic effects. Triterpenoids, saponins, flavonoids and phenolics have a positive correlation as anti-diabetic agents $[25,26]$.

Previously, anti-diabetic activity of another variety of this plant has been reported in the literature. Ethanol extract $(70 \%)$ prepared from the whole plant was evaluated for this study in alloxaninduced hyperglycemic mice. The plant exhibited a significant blood glucose lowering effect $(303.86 \pm 11.71 \mathrm{mg} / \mathrm{dL})$ when compared with that of the diabetic-untreated group (521.57 \pm 17.84 $\mathrm{mg} / \mathrm{dL}$ ) [27]. It can be hypothesized by the results obtained in correlation with the previous reports that there is a significant enzyme inhibition by alcoholic extract.

The anti-diabetic activity shown by the various extracts may be due to saponins, triterpenoids, polyphenols, flavonoids or other phytocomponents present in the plant. Therefore, further investigations are required to isolate and characterize terpenoids, saponins or other phytoconstituents responsible for $\alpha$-glucosidase inhibition.

\section{CONCLUSION}

F. indica Var. indica possesses anti-diabetic activity. Thus, the plant is a potential source of effective anti-diabetic therapeutic agent. Furthermore, the results lend some support for the traditional use of this plant in the management of diabetes mellitus.

\section{DECLARATIONS}

\section{Acknowledgement}

The authors are thankful to Dean and Principal University College of Pharmacy, University of the Punjab, Lahore and The University of Lahore for providing facilities during the research.

\section{Conflicts of interest}

No conflict of interest is associated with this work.

\section{Contribution of authors}

We declare that this research work was done by the authors named in this article and the liabilities pertaining to claims relating to the content of this article will be borne by the authors. The study was conceived and designed by Prof Dr Abida Latif. The plant was collected by Atiq-ur-Rehman and dried and pulverized by Dr. Imran Waheed. Experimental work was conducted by Atiq-urRehman and Dr Atta-ur-Rehman. Data handling and statistics application was done by $\mathrm{Dr}$ Muhammad Naeem Qaisar. The manuscript was written by Atiq-ur-Rehman and Dr Abida Latif. Dr Nasir Abbas has finally reviewed the manuscript. All authors read and approved the manuscript for publication.

\section{Open Access}

This is an Open Access article that uses a funding model which does not charge readers or their institutions for access and distributed under the terms of the Creative Commons Attribution License (http://creativecommons.org/licenses/by/ 4.0) and the Budapest Open Access Initiative (http://www.budapestopenaccessinitiative.org/rea d), which permit unrestricted use, distribution, and reproduction in any medium, provided the original work is properly credited.

\section{REFERENCES}

1. Mitra A, Dewanjee D, Dey B. Mechanistic studies of lifestyle interventions in type 2 diabetes. World $\mathrm{J}$ Diabetes 2012; 3(12): 201-207.

2. International Diabetes Federation (IDF). Diabetes Atlas. 7th edn. Belgium: Brussels; 2015.

3. World Health Organization. Global report on diabetes, 2016.

4. Kwon YI, Vattem DA, Shetty K. Evaluation of clonal herbs of Lamiaceae species for management of diabetes and hypertension. Asia Pac J Clin Nutr 2006; 15(1): 107118.

5. Tadera K, Minami Y, Takamatsu K, Matsuoka T. Inhibition of $\alpha$-glucosidase and $\alpha$-amylase by flavonoids. J Nutr Sci Vitaminol 2006; 52(2): 149-153.

6. Derosa G, Maffioli P. $\alpha$-Glucosidase inhibitors and their use in clinical practice. Arch Med Sci 2012; 8(5): 899906.

7. Mahayasih PG, Elya B, Hanafi M. Alpha-glucosidase inhibitory activity of Garcinia lateriflora Blume Leaves. $J$ Appl Pharm Sci 2017; 7(10): 100-104.

8. Stadler K. Oxidative stress in diabetes: In diabetes. New York: Springer; 2013; pp 272-287.

9. Dewi RT, Maryani F. Antioxidant and a-glucosidase inhibitory compounds of Centella asiatica. Procedia Chem 2015; 17: 147-152.

Trop J Pharm Res, April 2019; 18(4): 796 
10. Muhammad I, Takamatsu S, Walker LA, Mossa JS, Fong HH, El-Feraly FS. 2003. Cytotoxic and antioxidant activities of alkylated benzoquinones from Maesa lanceolata. Phyt Res. 17(8):887-91. doi: 10.1002/ptr.1237. [PubMed] [Cross Ref]

11. Zafar M, Khan MA, Ahmad M, Sultana S, Qureshi R, Tareen RB. Authentication of misidentified crude herbal drugs marketed in Pakistan. J Med Plants Res 2010; 4(15): 1584-1593. DOI: 10.5897/JMPR10.143

12. Eman AA. Morphological, phytochemical and biological screening on three Egyptian species of Fagonia. Acad Arena 2011; 3(1): 18-27.

13. Yaseen G, Ahmad M, Zafar M, Sultana S, Kayani S, Cetto $A A$, Shaheen $S$. Traditional management of diabetes in Pakistan: Ethnobotanical investigation from traditional health practitioners. J Ethnopharmacol 2015; 174: 91-117.

14. Trease GE, Evans WC. Pharmacognosy. 13th edn. London: Bailliere Tindall; 1989. pp 176-80.

15. Sofowora A. Medicinal plants and traditional medicine in Africa. 2nd ed. Ibadan, Nigeria: Spectrum Books; 1993. pp 1-153.

16. Chang $C$, Yang $M$, Wen $H$, Chern J. Estimation of total flavonoid content in propolis by two complementary colorimetric methods. J Food Drug Anal 2002; 10(3): 178-182.

17. Slinkard K, Singleton VL. Total phenol analysis: automation and comparison with manual methods. Am J Enol Vitic 1977; 28(1): 49-55.

18. Lee K, Shibamoto T. Antioxidant property of aroma extract isolated from clove bud [Syzygiun aromaticum (L.) Merr. et perry] Food Chem 2001; 74(4): 443-448.
19. African Journals Online (AJOL) [cited 2019 Feb 17]. Available from: https://www.ajol.info/index.php

20. Dahlqvist A. Method for assay of intestinal disaccharidases. Anal Biochem 1964; 7(1): 18-25.

21. Bergmeyer HU, Bernt E. Determination of glucose with glucose oxidase and peroxidase. Methods Enzymatic Anal 1974; 2: 1205-1215.

22. Kazeem MI, Azeez GA, Ashafa AO. Effect of senna alata $(L)$ roxb (fabaceae) leaf extracts on alpha-amylase, alpha-glucosidase and postprandial hyperglycemia in rats. Trop J Pharm Res 2015; 14: 1843-1848.

23. Jo SH, Ha KS, Moon KS, Lee OH, Jang HD, Kwon YI. In vitro and in vivo anti-hyperglycemic effects of Omija (Schizandra chinensis) fruit. Int J Mol Sci 2011; 12(2): 1359-1370.

24. Siddaraju MN, Dharmesh SM. inhibition of gastric $\mathrm{H}_{+}, \mathrm{K}+$, ATPase and Helicobacterpylori growth by phenolic antioxidants of Curcuma amada. J Agric Food Chem 2007; 55(18): 7377-7386.

25. Jouad H, Haloui M, Rhiouani H, El Hilaly J, Eddouks M. Ethnobotanical survey of medicinal plants used for the treatment of diabetes, cardiac and renal diseases in the North centre region of Morocco (Fez-Boulemane). J Ethnopharmacol 2001; 77: 175-182.

26. Yin Z, Zhang W, Feng F, Zhang $Y$, Kang W. $\alpha$ Glucosidase inhibitors isolated from medicinal plants. Food Sci Hum Welln 2014; 3(3): 136-174.

27. Mahdy A, Shehab NG. Hypoglycemic activity of Fagonia indica and Aloe vera in aloxan-induced hyperglycemia in Mice. EC Pharm Sci 2015; 2: 239-244. 